\title{
School-Immigrant Family-Community Collaboration Practices for Youth Integration
}

\author{
Khaoula Boulaamane, Yamina Bouchamma \\ Faculty of Education, Department of Educational Foundations and Practices, Université Laval, Québec QC, Canada \\ Email: Khaoula.boulaamane.1@ulaval.ca, Yamina.Bouchamma@fse.ulaval.ca
}

How to cite this paper: Boulaamane, K., \& Bouchamma, Y. (2021). School-Immigrant Family-Community Collaboration Practices for Youth Integration. Creative Education, 12, 62-81.

https://doi.org/10.4236/ce.2021.121006

Received: November 26, 2020

Accepted: January 12, 2021

Published: January 15, 2021

Copyright (อ 2021 by author(s) and Scientific Research Publishing Inc. This work is licensed under the Creative Commons Attribution International License (CC BY 4.0).

http://creativecommons.org/licenses/by/4.0/

\begin{abstract}
We examined "school-family-community" collaboration in a context of ethnocultural diversity to identify and analyze collaborative practices involving immigrant families. Interviews were conducted in Québec with 11 education stakeholders, 10 community representatives, and 7 members of immigrant-origin families. Our conceptual framework was inspired by Bronfenbrenner's ecosystems model (1979) and Epstein's overlapping influence approach (2001). Thematic analysis brought forth two dimensions favoring collaboration: leadership and the child's perception of the integration process. Our results nevertheless show that school-immigrant family-community collaboration remains hindered by the trust issues and reluctance of certain partners, thus calling for additional resources and investments by every level concerned, particularly government decision makers.
\end{abstract}

\section{Keywords}

Immigrant Families, Educators, Community, Leadership, Practices

\section{Introduction}

In the last twenty years, the observed increase in the number of immigrants has become a growing concern in almost all of western civilization (Ali \& Fokkema, 2015). The province of Québec is also experiencing a significant rise in the number of new arrivals, particularly outside the greater Montréal area (ISQ, 2017; Bakhshaei, 2015). Unfortunately, in many schools, this increase has not been met by the addition of the appropriate support and welcome measures (Bouchamma, 2015, Vatz Laaroussi \& Steinbach, 2010).

Scientific and political discourse in Québec has generally centered on collaborations between the school-family-community (SFC) and specifically in contexts of ethnocultural diversity (CSÉQ, 2017; Deslandes, 2019a, 2019b; Ep- 
stein et al., 2019; Kanouté, 2016; Larivée, Bédard, Couturier, Yalubi et Larose, 2017; MEES, 2020; MELS, 2014). In this regard, the Cadre de référence sur l accueil et I intégration des élèves issus de limmigration (MELS, 2014) proposes a section covering the theme of SFC, and more recently, the Coalition Avenir Québec party's Governance Plan in Education (CAQ, 2018) emphasizes that the school must "belong to its neighborhood" because both the teaching and non-teaching staff are in fact actors for change in identifying the needs of their environment. Furthermore, in this context, the principal's role is instrumental by encouraging and supporting partnerships with the community and getting the school team and the families on board (OFDE, 2020).

Although efforts have examined the SFC dynamic, few studies have actually reported on the school's relationship with immigrant-origin families (Beauregard \& Grenier, 2017) and even less is known regarding the school-community interaction (Larivée et al., 2017). We therefore raised the following question: Which school-immigrant family-community (SIFC) collaborative practices promote the successful integration and achievement of immigrant students?

\section{Characteristics of SIFC Collaboration}

In a context of immigration, SIFC collaboration provides numerous advantages, including literacy support for each student (Bhattacharya, 2010) and their academic achievement (Bissonnette, Toussaint, Martiny, Fortier, \& Ouellet, 2019). This collaboration also opens schools to the different realities and challenges of immigrant-origin families (Charrette \& Kalubi, 2016) and contributes to improving the quality of equity-based educational services, developing engagement within the community and its families, and creating enriching activities for all children, regardless of their characteristics (Bryan, Griffin, Kim, Griffin, \& Young, 2019).

Nevertheless, the successful sustainment of SIFC collaborations is often challenging because: 1) Schools involuntarily focus most often on families in general than on immigrant families or those of diverse ethnicities or cultures (Kim, 2012); 2) community subsidization for SIFC programs is often not extended (Charette et al., 2019); and 3) teachers have the dual task of encouraging French literacy while dealing with immigrant families who are not always open to learning and using the host language (Benoit, Rousseau, Ngirumpatse, \& Lacroix, 2008). SIFC collaboration thus requires the commitment of several stakeholders, including education consultants and community workers.

The involvement of school counselors is crucial for effective SIFC collaboration (Cook, Hayden, Bryan, \& Belford, 2016), as these specialists can contribute to supporting pro-active activities to sustain student achievement and lasting social and affective improvement (ASCA, 2012). As for community workers, these partners help strengthen the relationships with schools to meet the expectations of families and their children, particularly immigrant-origin ones (Audet \& Potvin, 2013).

To our knowledge, no other study in Québec has identified SIFC collaboration 
practices in the specific context of immigration while taking into account the perspectives of the school, the community, and the immigrant families they serve, and an overall portrait of these practices is thus absent in the literature. Indeed, Molina (2013) noted the absence of pedagogical guidelines that not only describe the steps to develop strong SFC ties but also are readily adaptable to all contexts. For Brougère (2005), the lack of appropriate reference standards that can be shared between the various education and community stakeholders has led professionals to use practices that are not easy to define, structure, and interpret. The general objective of this study was thus to identify and analyze the main types of currently used SIFC collaboration practices.

\section{Theoretical Framework}

The conceptual framework of this study was composed of the key concept related to SIFC collaboration, based on 1) the ecological systems theory of Bronfenbrenner (1979) and 2) the overlapping influence model of Epstein (2001), which are illustrated in Figure 1.

Bronfenbrenner's model (1979) centers on the notion that a child's general environment affects their development. This development appears through the interaction of several systems: microsystem, mesosystem, exosystem, macrosystem,

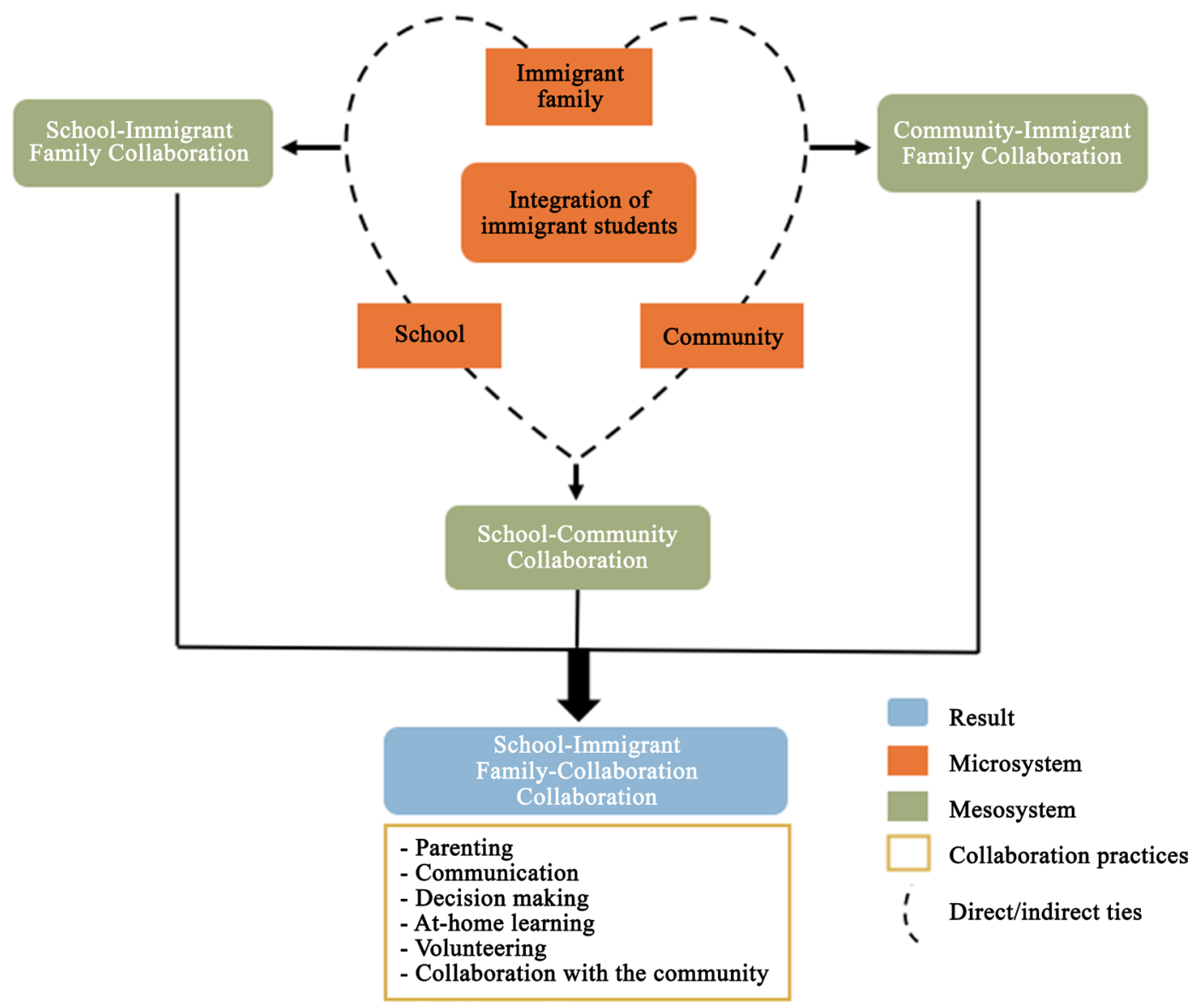

Figure 1. Conceptual representation of SIFC collaboration. 
ontosystem, and chronosystem. For the purposes of the present study, we retained the mesosystem which houses four types of interconnections: 1) multisetting participation; 2) indirect linkage; 3) intersetting communications; and 4) intersetting knowledge (pp. 209-210). Here, we focused on the first two forms: multisetting participation (direct network) and indirect linkage (representing existing intermediate connections).

Epstein's approach, on the other hand, is considered as a strong basis on which to build and operationalize SIFC collaboration practices (Epstein, 2001). This model is grounded in the forces existing in all of the stakeholders and is defined by six dimensions of parental involvement: 1) the school's support of the parental role; 2) school-family communication; 3) parent recruitment as volunteers; 4) the school's support of the parents in at-home learning; 5) the parents' involvement in the school's decisions; and 6) collaboration with the community to support the school's programs and coordinate efforts with the families and the students. Figure 1 illustrates the theoretical framework of the present study.

\section{Methodology}

This section presents our research methodology, including participants as well as coding and data analysis methods. Our research objective was to identify and analyze the SIFC collaboration practices favoring the educational success and integration of immigrant-origin students. This qualitative descriptive study was conducted using semi-structured interviews (25 to 70 minutes in length) in which the participants detailed their respective SIFC collaboration practices. This study was approved by the Université Laval Research Ethics Committee (no. 2019-373/08-01-2020) and the participants signed a consent form.

\subsection{Participants}

Based on a non-probability sampling, the participants $(n=28)$ included 11 representatives of elementary and secondary schools that welcomed immigrants (3 principals and 8 school members), 7 members of immigrant-origin families, and 10 community members ( 5 administrators and 5 community workers). All of the participants were located outside the Montréal area.

1) School representatives

In total, eight elementary $(n=8)$ and three secondary $(n=3)$ schools (deprivation index 6.1) participated in this study. The schools contained, on average, 53 teachers and 860 students, including 338 immigrant youth hailing from Africa, Asia, Haiti, Cuba, Venezuela, and America, among others. Of the 11 school members, 10 were women with an average of six years of teaching experience. The schools were all located outside of Montréal in cities where immigration was less prevalent: Québec City $(\mathrm{n}=6)$, Saint-Constant $(\mathrm{n}=2)$, Saint-Jérôme $(\mathrm{n}=1)$, Saint-Anselme $(\mathrm{n}=1)$ and Longueuil $(\mathrm{n}=1)$.

2) Immigrant families

The members of the participating families $(n=7)$ included five mothers (from 
Morocco, India, Cameroon, Senegal, and Colombia) aged between 36 and 45 years who had child in elementary school (grades 1 to 5).

3) Community members

The community representatives $(n=10)$ included eight women and two men who had an average of seven years of professional experience. They hailed from different cities (Sherbrooke, Québec, Drummondville, Chicoutimi, and Beauharnois).

\subsection{Coding and Analysis}

The transcribed verbatims were gathered using QDA Miner software and were subsequently subjected to thematic analysis following the method of Braun, Clarke, \& Weate (2016) who categorized the data into three levels, namely, overarching themes, themes, and sub-themes. Our data thus consisted of three types of general collaboration: 1) School-Immigrant Family (SIF); 2) Immigrant Family-Community (IFC); and 3) School-Community (SC). These general themes were composed of two themes generated by our conceptual framework.

- Theme 1 regarded the collaboration practices according to the dimensions laid forth in the model of Epstein (2001). These dimensions represented the following sub-themes: parenting, communication, volunteering, at-home learning, and decision making. The sixth dimension (collaboration with the community) was not taken into account here, as it constituted the second theme.

- Theme 2 referred to the collaborative ties according to the mesosystemic model of Bronfenbrenner (1979) and contained two sub-themes: direct tie and indirect tie.

Two prominent sub-themes pertaining to the collaboration practices were identified: leadership and the child's experience during the process. Figure 2 presents a schematic view of the code list.

\section{Results}

This section presents the results of our observations, as well as the collaboration practices and the connections emerging from each general theme.

\subsection{School-Immigrant Family Collaboration (SIF)}

\subsubsection{SIF Collaboration Practices}

Communication. Our results show the presence of strong communication
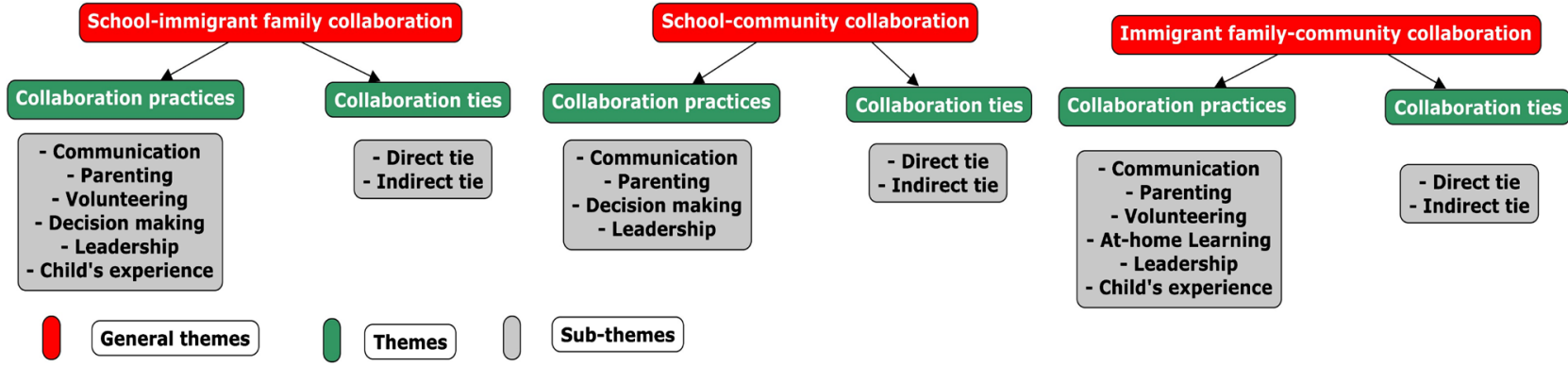

Figure 2. Schematic view of SIFC collaborative practices and ties. 
between the teachers and the immigrant parents. Indeed, the teachers kept the immigrant families informed regarding the activities undertaken, their child's progress, the rules and regulations, etc. As for the other school participants, some acknowledged that immigrant families were often reluctant and did not always openly express their concerns to them, even if the teachers were available and willing to listen; other participants spoke of a lack of communication with immigrant families or students and that their role was limited to supporting the teacher in supporting the student.

I'm not the one in contact with the family [...] I communicate only with the teacher. (Education consultant 1 )

Moreover, most of the immigrant families in our study stated only communicating with the school principals during Parent Council meetings or at the beginning of the school year during Open House Day activities. This day is generally used by schools to relay vital information to immigrant families on how the Québec education system works.

One of our priorities was to really take the time to welcome each student.

$[\ldots]$ we organized a welcome meeting with or without interpreter. (Principal 1)

SIF communication took place several ways, including information placed in the child's binder for the parents, apps or platforms, letters sent by mail, or phone calls, among others. Meetings were less encouraged but were possible by appointment or on certain mandatory occasions, such as report card day. Only a few of the schools in our study called in interpreters in instances of a language or cultural barrier.

Parenting. Only one immigrant family spoke of the support they received from a social worker in the form of a personalized work plan to help their child; however, this family appeared not to be completely satisfied, because this assistance was of limited duration and the actions were arduous.

She said that she couldn't help me anymore, that if I still needed help that I could go to a hospital. (Mother 1)

Volunteering. At the school's request, some families volunteered for certain activities to help the teachers organize events and to assist them during outings.

Decision making. In the entire cohort under study, the schools determined their programs, initiatives, activities, and schedules, with no input from the immigrant families in these decisions. The schools did, at times, solicit the participation of the parents at certain meetings (Parent Council, organizing committees) to share their opinion and vote on certain activities, for example; these meetings, however, always dealt with education matters and teaching in general, and rarely on issues or challenges related to the reality of immigrant students.

But the meetings don't concern the problems of immigrants; they are more on education. (Mother 5) 


\subsubsection{SIF Collaboration Ties}

SIF collaboration often occurred through an indirect relationship in which the community played an important intermediary role by 1 ) distributing posters to inform the parents regarding certain school services; 2 ) following up with immigrant parents relative to certain demands; 3 ) helping them to organize their daily school routine (meals, service costs, etc.); 4) clarifying the expectations and obligations of the two parties involved; 5) directly resolving certain issues when there is a lack of understanding; and 6) indirectly guiding immigrant families closer to their school. The children are also instrumental players by expressing their needs to the teachers who in turn call upon the community for support.

We'll try to work with the family, with our own multicultural approach, get them interested, try to explain what the school expects of them, and on the other hand, we'll work with the school to put things into perspective, we'll explain things like understanding their migratory path of the family, whether they have difficulties, and how we can work together on this. (Community coordinator 1)

Despite the fact that most of the immigrant families in our study communicated with their school, they did point out a lack of direct follow-up by the school relative to the information they received.

Not much involvement. If I want to enrol them, I do it and it ends there. And the school doesn't really get involved. They send us flyers which they get from the community workers. But as for the school's direct involvement, there isn't any. (Mother 4)

As for the school's attempts to communicate with the families, this often fell on deaf ears because of the school's lack of clarity and experience making sustained connections and organizing relevant activities.

There are sometimes attempts, but we don't have enough experience and so the parents, they way we approach them, it can just be information sent by email, they don't understand it, don't read it, and ultimately don't come. Nothing's adapted for them. (Teacher 3)

\subsection{Immigrant Family-Community Collaboration (IFC)}

\subsubsection{IFC Collaboration Practices}

Communication. Generally speaking, community workers are there to communicate with immigrant families. They are mostly the initiators of these interactions to learn about the family's situation, discuss the issues their children may be having, and propose appropriate solutions. They meet with them in an open-door environment or contact them by phone or email. The immigrant families primarily learn of the community's activities through word-of-mouth, newspapers, internet, etc.

Parenting. The community workers participating in this study listed several activities organized for immigrant families, such as welcoming and guidance 
(housing, getting settled, document translation, in-home meetings, etc.); adapting to the host society (information workshops, interpreters, volunteering, daycare, courses, etc.); and references to other resource organizations (health and social services, among others). The community's approach is characterized by a closeness with the families and a knowledge of the family environment. One participating organization stated that before any activity can be proposed, one must first analyze the family's needs.

Volunteering. Some immigrant families directly offered to volunteer in the community to learn new cultures, integrate more easily, support other parents at school, assist in the planning of workshops, or help celebrate holidays or other milestones.

Like me, at the library, I myself chose to sign up to volunteer. (Mother 5)

At-home learning. All of the community organizations in our study provided activities for immigrant families to assist the integration and educational success of their children (e.g., information workshops on the host education system, enrollment, and tutoring).

\subsubsection{IFC Collaboration Ties}

IFC collaboration appeared as a direct partnership, despite being mostly solicited early in the process to help ease the families' acclimatization, adaptation, and integration. However, this collaboration was not without issue, as many community workers mentioned that families were often distrustful and thus did not always express their needs, which made discussion both difficult and complex. In their defense, the immigrant families explained that access to activities was often hampered by complicated enrollment procedures and waiting times.

Sometimes, they're reluctant $[\ldots]$ so even a family in need will not necessarily say so off the bat. (Liaison officer 1 )

\subsection{School-Community Collaboration (SC)}

\subsubsection{SC Collaboration Practices}

Communication. SC communication was mostly initiated by community workers who facilitated the exchange of information and relevant assistance. Some community members related having gone to the school to present their mission and activities, discuss a family's concern with teachers, or better understand a situation involving certain immigrant-origin youth, among others, while others stated that contact with the school was made by phone or email when relations were smooth with the school and the principals knew their organization. Consequently, some principals would call upon a community representative during the school's meet and greet day. Two community workers added that one of their jobs was to be present in the school in an office to be close to the teaching staff.

What I try to do is one day, say, Monday in the office, Tuesday and 
Wednesday at the school, then Thursday and Friday in another school. So, I am physically present in the school, I participate in the teachers' meetings (Liaison officer 2)

One teacher did not understand this type of position in their school.

I don't know exactly how their job was created [...] who funded the project. Was it really the school or did the organization come in and ask the school? (Teacher 1)

In contrast, several community actors mentioned the indifference, reluctance, and even lack of awareness of many principals regarding collaboration in the context of immigration.

There are still some principals who, either involuntarily or just a lack of interest in this reality, they start being prejudiced, clichés, even a reluctance to collaborate with certain families. It's not always a pretty sight. (Community coordinator 1)

This non-involvement by the school negatively affected the motivation and anticipation of some community representatives who admitted no longer communicating directly with the school without having prior approval or an obvious mutual interest.

I encourage the parent to go by themselves. If they're uncomfortable, I can offer to accompany them but I know that first we have to run it by the school to see if they're interested, if it's possible, if someone will be there to meet with us. (Organization leader 2)

Parenting. Only one school participant confirmed that an activity had been organized that involved the community to plan information workshops on the subject of parenting skills.

Decision making. Very few participants confirmed the presence of both the school and the community at certain important meetings (e.g., Parent Council and Neighborhood Round Tables), despite the possibility of establishing strategic agreements on such issues as how to deal with suspended students. One immigrant family member and one community worker mentioned practices that were used in collaboration with both the school and the community, such as ski outings and gardening activities, and the majority of the community workers stated not having had discussions with the school regarding the organization and planning of activities and practices for immigrant children and their families.

Everything that concerned planning, I just wasn't present (Liaison officer 1)

\subsubsection{SC collaboration Ties}

In general, school-community collaboration took place directly and indirectly, and for most of the participants from these two sectors, this collaboration appeared to be both difficult and rigid. 
Why collaboration's difficult, I don't know. Maybe sometimes they're tired, overworked; but you know, everyone is tired [...] And we've been asking for this collaboration for years for the kids. (Organization leader 1)

The participants thus admitted their lack of understanding of this collaboration, its difficulty, and its absence. While some school members mentioned lacking information regarding the resources or practices established for immigrants, others stated that the school simply had none.

I think a link should be established between the school and the community because right now there isn't really one. (Teacher 1)

Some schools viewed the community as a resource for certain mundane issues, such as providing a meal to a child who had none:

They'll just call me and say: "So ... we've got a child with no lunch. Can you send one?” They use us like a resource [...] sometimes it's negatively perceived $[\ldots]$ as if we pick up after all the poverty around here (Organization leader 1)

Many of our participants believed that one of the main reasons explaining this complexity was the fact of standardizing school practices and regulations, which did not always guarantee satisfactory results and fair outcomes for all concerned.

It's because of the standard requirements and regulations applicable to Québec families which we continue to apply to newly arrived families. (Community coordinator 1 )

Our participants also expressed that time was an important factor in successful SIFC, an element that schools often lacked; the situation is therefore not conducive to collaboration and the planning of specific activities for immigrants.

I don't see how they'll have the time to do something with a community organization. (Education consultant 2)

Some community members acknowledged that because the focus of their organization was supporting the welcoming and integration of immigrant families and their children, SIFC collaboration was not considered a priority among most of these organizations.

The SFC project, let's just say that it's a small part of what my organization does as such and it's also a very small part of the budget for all of our activities [...] so, the biggest portion of our organization's funding in general; as I said, it's really on the level of the initial efforts to set them up (Liaison officer 1 )

However, the principals in our study remained positive and open to collaborating and welcoming immigrant families and their children.

Well, I think we could do better. (Principal 2) 


\subsection{Prominent Sub-Themes}

\subsubsection{Leadership}

Parental leadership. The immigrant parents were motivated to do activities with their children at home (tutoring, reading, etc.) and to integrate them into the host society (enrollment in community activities, getting to know the neighborhood, etc.), with the goal of a) adopting their traditions; b) motivating their children or learning about their difficulties; or c) playing the role of parent far from their homeland.

Political leadership. The participating community actors identified well-defined actions to favor the successful integration of immigrant families and their children. The focus was thus on teamwork to consolidate their efforts, recruit workers and administrators on a continuous basis, and collaborate with other partners when necessary (culture-based organizations, youth centers, school districts, etc.) to obtain financial support, resolve issues, or rent space for their activities. The political leadership of the community also resides in its willingness, its open attitude, and its negotiation skills with the school in implementing educational projects. Although the school is reluctant to collaborate with some of these organizations, community workers and leaders remain insistent and persist in their discussions with the school to establish vital agreements for the benefit of all concerned parties.

You have to push forward. I have to be the one to push. (Organization leader 2)

I think that social workers are more invested than schools are. (Teacher 2)

Our findings also reveal that one teacher had taken on the role political leader. This person was of particular interest because of her personal and informal work approach, her innovative skills and resourcefulness, her devotion and dynamic attitude, and her constant support. Although not part of her duties, this teacher was happy to rapidly accompany immigrant families and refer them to the appropriate community resources they needed.

It's not part of my job, but when I see there's a problem, I offer to help [...] a sort of consultant, if you will, who is not officially mandated as such.

(Teacher 1)

Collaborative servant leadership. Both the participating principals and the community organization leaders stated being open to their staff's involvement in the decision-making process and the development of objectives, as well as activity planning, the proposal of new projects, and participating in meetings.

I see myself more as the one who sets up the conditions, means, and resources that could help the team do its work and respond to the needs in the field. (Principal 1)

However, these school meetings generally concerned discussions on the values of education and how the school system worked. Very few meetings appeared to 
be specific to the context of immigration, such as, for example, the committee organized to discuss the francization issues of immigrant-origin students, or the professional development day. Of interest is that only one school in our study collaborated with its school district to develop welcome guidelines for immigrants in which the latter's concerns relative to their welcome and integration were addressed.

We are actually working on developing a welcome protocol $[\ldots]$ when the parent arrives, who they go to, the importance of meeting with the family before integrating the child into the school to help us understand their migration, where they've come from. (Education consultant 1)

\subsubsection{The Child's Experience}

The participants related the relevance of the immigrant child's experience in the SIFC dynamic. The latter appeared to be more motivated than were their peers and more openly valued education in the attainment of their personal goals. The principals thus emphasized the importance of considering the basic needs of immigrant youth to better understand their expectations and to help them fully integrate and succeed.

We have to make sure that the child who arrives here, who is experiencing so much destabilization on so many levels [...] that they feel safe at school. Focusing on learning a second language and all that means nothing if the child doesn't physically feel at home in their new environment. (Principal 1)

Although the open-mindedness of the principals in our study was palpable, we did notice that these leaders received no training to accomplish the tasks involved.

We've received no training on how to appropriately welcome an immigrant student. (Principal 2)

Most of the schools in our study organized several activities for all of their students, whether within its walls, such as sports (soccer, basketball, ski), parties (end-of-year, Hallowe'en, pyjama parties, other theme-inspired events) or educational workshops (lectures and team projects), or outside activities such as culture/history-themed outings, picnics), to name but a few. In response, all of the participating parents mentioned that these events, organized for all of the students, did not always meet the needs of immigrant children; indeed, among all of these various workshops and activities, very few were adapted for immigrant students.

I think that we are blatantly ignoring the needs, what we could do more or differently for these students [immigrants]. We treat them like everyone else, we think we are treating them fairly, but in fact we're not because sometimes there may be different needs that are being ignored. (Teacher 1) 
The community members in our study also listed several practices deployed to support the integration of immigrant children through local organizations: sports (tennis, soccer, karate, taekwondo); social actions (food banks, clothing, discussions); cultural activities (Easter, end-of-year events, cooking classes); extracurricular/educational opportunities (sociolinguistic workshops, tutoring, and reading, writing, and numeracy awareness). Other outside activities, such as outings (skating, museums, movies theatres) and summer camps, were also mentioned. Although all of the organizations we interviewed did not separate immigrant and non-immigrant children during their activities, they nevertheless stated being open to all children, regardless of their characteristics, the goal being to teach them such values as fraternity, respect, and acceptance, and to help those experiencing difficulties at school or mental, emotional, or behavioral issues.

We do have a system of values, like respecting differences, culture, etc., so the children know. (Community leader 3 )

Three services provided for immigrants caught our attention. One center exposed their plans for a summer camp, which they referred to as a "welcome and integration camp" proposed exclusively for immigrant children. Another organization provides reduced bus fare for immigrant families and their children and disadvantaged persons for easier access to their facilities. Lastly, a third center has organized an annual intercultural meet and greet to bring immigrant and Québec families together in a spirit of exchange, new friendships, and learning about the different cultural realities within the community.

Finally, the community representatives had their indirect relationship with the children. Their involvement with immigrant families can be explained by the fact that the parents can influence how their children integrate in and adapt to the new host society. The community can thus learn about the family's context toward a broader understanding of the child's situation at school.

Of course, when we accompany the parents, or families in general in their integration process when they first arrive, of course, there, indirectly, the children also participate in this integration process. (Liaison officer 2)

\section{Discussion}

The goal of this study was to identify and analyze the SIFC collaboration practices of the three instances involved, namely, the school, immigrant families, and the community. On the basis on our findings, five major observations emerged.

1) In SIF collaboration, communication was evidenced more between immigrant families and teachers than with the school (SIF), and the measures used by the teachers to communicate with these families were no different than those used with Québec families. Beauregard and Grenier (2017) also observed this in their study. Indeed, very few comments referred to communication that was specific to immigration issues. In addition, except for the welcome and franciza- 
tion class, no activities proposed by the school were specifically for immigrants, therefore suggesting more of a general SF collaboration than an SIF collaboration. This result clearly shows that these practices should be considered among the basic actions among the triple mission of Québec schools, namely, to educate, socialize, and qualify (Ministère de l'Éducation du Quebec, 2006). Further to this, immigrant families were not involved in the decisional processes as such; attending school meetings did enable them to discuss education-related concerns with certain school members but did not allow them to plan activities, draw a schedule, or organize programs, among other actions.

2) The practices pertaining to at-home learning and to parenting were exercised more in IFC collaboration than in SIF collaboration. It is thus the community who helps immigrant families to educate their child, understand the school system, and learn about and adapt to the host society's habits and culture. The IFC tie is therefore highly relative, depending on the family's issue, and the community's offer of support remains highly collaborative. Nevertheless, structuring SIFC initiatives is not among the priorities of most community organizations, whose main objective is to welcome and accompany newly arrived families; this suggests that the collaborative approach remains something that is both underdeveloped and ill-defined.

3) SC collaboration was fragile and difficult, and progressed at a snail's pace. This may be explained by (a) the lack of clarity as to the school's responsibilities and those of the community organization and (b) the revolving door phenomenon regarding school principals, which may affect communication and pre-established agreements.

4) The SIFC collaboration ties were highly relative to each situation. Indeed, practices either varied little or were ill-adapted to immigration contexts, and the dimensions described in Epstein's work did not entirely equate with the reality of collaboration in a context of diversity. Behaviors such as reluctance and mistrust were prevalent among the education and social-sector representatives, which, ultimately, is detrimental to sustaining fruitful SIFC collaboration.

5) Lastly, two dimensions were identified to complete Epstein's model (2001): leadership and the immigrant child's perspective of the entire adjustment process.

- Leadership was indeed an instrumental form of involvement, as each stakeholder took on the role of leader. This phenomenon was reported in a national study on education consultants (Griffin \& Steen, 2010). Parental leadership was prominent in our results, as supported by the definition proposed by Bellon, Ngware, and Admassu (2017): "Parental leadership is the influence process whereby parents interact with their children in a context of home and school environments toward achievement of the desired academic goals" (p. 111). Our participants also referred to the political leadership of the community, according to the characteristics defined by Gallos (2013), the most important of which is developing a "friends" zone, particularly with the most honest ones (Sawicki, 2003). Finally, the role of the community and that of school 
leaders in consolidating work teams is indicative of collaborative servant leadership, which represents a significantly positive element. Indeed, in their longitudinal findings, Hallinger and Heck (2010) showed that this form of leadership had an indirect positive influence on children's learning development by improving the educational competency of schools. Empirical research has also developed and demonstrated this altruistic model of collaborative leadership in the school setting through such variables as "school culture, microclimate, employee job satisfaction, commitment, citizenship behavior, professional growth and learning of a leader, student's achievement improvement, and others" (Pilkiene, 2017: p. 116).

- The child s perspective or experience brings us to the immigrant student, at the heart of the SIFC dynamic. Their relationships with their peers and their teachers are an extremely important part of the equation in how we encourage their academic achievement (Bissonnette et al., 2019). It is thus imperative that we take into account their needs and experiences: to help them in their role as child; to ensure that they receive the appropriate education by developing activities on every aspect (educational, pedagogical, social, cultural, physical activity, etc.); to establish a direct connection with them to learn about their needs, expectations, and life goals; to provide them with basic support resources (health, nutrition, clothing); to organize personalized interventions when issues arise; and finally, to heighten their awareness of the child-family-community connection.

SIFC collaboration thus warrants a series of specific goals, practices, and actions. In light of our results, future research should closely examine the conditions, training, and guidance that are most likely to influence this active collaboration. The conditions under which collaboration practices are developed in a context of immigration must not be neglected, as they rely heavily on the availability of material resources (time, equipment, etc.), qualified human resources, and fairness-driven practices, as well as on the well-defined roles of its advocates. Indeed, despite the fact that these actors are functionally organized, regularly interact, and acknowledge the importance of collaboration, professional training for all of the partners involved in this collaboration must be provided to boost confidence, nurture trust, and enhance competence with regard to the many different delicate issues they are called upon to deal with on a daily basis. Greater task diversification should also be envisaged. As for the families of immigrant youth, we must continue to invest in strengthening their awareness of their education-related obligations and their role in this vital partnership. To sustain these efforts, however, this support cannot be successfully achieved without government initiatives and the commitment of school principals and local community centers.

\section{Conclusion}

We examined the collaborative practices and connections in the specific context 
of immigration through the eyes of three groups of interest, namely, schools, immigrant families, and community organizations. Our results confirm the presence of communication between the three instances, an interest on the part of immigrant families for volunteering, active teamwork in both the school and the community, collaborations between community organizations, and the sensitivity of schools toward the experience of immigrant-origin youth. However, our findings also reveal no tangible decisional power of immigrant families at school, a lack of supervision by schools relative to at-home learning and parental involvement, the daunting challenges community organizations face regarding funding renewal, and the reluctance of both immigrant parents and schools toward collaborative actions.

Despite the benefits of collaboration with the community, principals continue to be ill-equipped in terms of resources and targeted professional development to ensure and sustain effective SIFC partnerships. As for the community workers, these participants estimated that immigrant families were satisfied with the services they provided but that their level of effectiveness in supporting integration and student achievement is a constant challenge: having to exercise patience when dealing with many community partners; directing needs-based projects; maintaining the continuous involvement of the school; and getting immigrant parents to better voice their needs and expectations.

To conclude, further research in this area should consider the experience of the immigrant child and broaden community contribution to include government decision-makers who have greater strategic leverage. Furthermore, due to the evident lack of a structured outline of collaborative practices in the field as well as in the literature, it would be of interest to constitute such a list and make it available to all stakeholders who currently have no reference materials or guidelines, no clear definition of the related roles and needs, and the underexploited involvement of the two main protagonists in this collaboration, namely, the school and the community.

\section{Conflicts of Interest}

The authors declare no conflicts of interest regarding the publication of this paper.

\section{References}

Ali, S., \& Fokkema, T. (2015). The Importance of Peers: Assimilation Patterns among Second-Generation Turkish Immigrants in Western Europe. Journal of Ethnic and Migration Studies, 41, 260-283. https://doi.org/10.1080/1369183X.2014.921114

American School Counselor Association (2012). ASCA National Model: A Framework for School Counseling Programs.

https://schoolcounselor.org/ascanationalmodel/media/anm-templates/anmexecsumm. pdf

Audet, G., \& Potvin, M. (2013). Les intervenants communautaires-scolaires dans des quartiers defavorises et pluriethniques de Montreal: Synthese comparee des initiatives 
et etat de la situation [Community-School Workers in Montréal's Disadvantaged and Multi-Ethnic Neighborhoods. Compared Analysis of Initiatives and Overview]. https://centreinteractions.ca/publication/les-intervenants-communautaires-scolaires-d ans-des-quartiers-defavorises-et-pluriethniques-de-montreal/

Bakhshaei, M. (2015). La scolarisation des jeunes quebecois issus de l'immigration: Un diagnostic [Educating Immigrant-Origin Youth in Québec].

https://fondationchagnon.org/media/1603/rapport recherche diagnostic enfants issu s immigration version finale.pdf

Beauregard, F., \& Grenier, N. (2017). Pratiques de communication de parents immigrants et d'enseignantes titulaires au primaire [Communication Practices of Immigrant Parents and Elementary School Teachers]. La revue internationale de l'éducation familiale, 41, 127-154. https://doi.org/10.3917/rief.041.0127

Bellon, E. O., Ngware, M. W., \& Admassu, K. (2017). The Role of Parental Leadership in Academic Performance: A Case of Pupils in the Free Primary Education Program in Kenya. Education and Urban Society, 49, 110-130. https://doi.org/10.1177/0013124516630604

Benoit, M., Rousseau, C., Ngirumpatse, P., \& Lacroix, L. (2008). Relations Parents Immigrants-écoles dans l'espace montréalais: Au-delà des tensions, la rencontre des rêves [Immigrant Parent-School Relationships in Montréal: Beyond the Tensions, Dreams Exist]. Revue des sciences de l'éducation, 34, 313-332.

https://doi.org/10.7202/019683ar

Bhattacharya, A. (2010). Children and Adolescents from Poverty and Reading Development: A Research Review. Reading and Writing Quarterly, 26, 115-139.

https://doi.org/10.1080/10573560903547445

Bissonnette, M., Toussaint, P., Martiny, C., Fortier, G., \& Ouellet, F. (2019). Perception de membres de la communauté éducative des facteurs de réussite et d'échec des élèves issus de l'immigration d'écoles secondaires défavorisées et pluriethniques montréalaises [Educators' View of the Failure/Success Factors of Immigrant Youth from Disadvantaged and Multi-Ethnic Montréal High Schools]. Revue des sciences de l'éducation de McGill, 54, 1-18. https://mje.mcgill.ca/article/view/9430 https://doi.org/10.7202/1060861ar

Bouchamma, Y. (2015). L'école et l'immigration: Défis et pratiques gagnantes [School and Immigration: Challenges and Winning Practices]. Lévis: Les éditions de la Francophonie.

Braun, V., Clarke, V., \& Weate, P. (2016). Using Thematic Analysis in Sport and Exercise Research. In B. Smith, \& A. C. Sparkes (Eds.), Routledge Handbook of Qualitative Research in Sport and Exercise (pp. 191-205). London: Taylor \& Francis (Routledge).

Bronfenbrenner, U. (1979). The Ecology of Human Development: Experiments by Nature and Design.

https://khoerulanwarbk.files.wordpress.com/2015/08/urie bronfenbrenner the ecolog y of human developbokos-z1.pdf

Brougère, G. (2005). Parents et professionnels face a l'accueil et a l'education du jeune enfant [Parents and Professionals: Welcoming and Educating Children]. In S. Rayna, \& G. Brougere (Eds.), Accueillir et eduquer la petite enfance: Les relations entre parents et professionnels (pp. 9-23). Paris: INRP.

Bryan, J., Griffin, D., Kim, J., Griffin, D. M., \& Young, A. (2019). School Counselor Leadership in School-Family-Community Partnerships: An Equity-Focused Partnership Process Model for Moving the Field Forward. In S. B. Sheldon, \& T. A. Turner-Vorbeck (Eds.), The Wiley Handbook on Family, School, and Community Relationships in Education (pp. 265-287). Hoboken, NJ: Wiley Blackwell. 
https://doi.org/10.1002/9781119083054.ch13

CAQ Coalition Avenir Québec (2018). Plan de gouvernance scolaire: Remettre l'ecole entre les mains de sa communaute [Governance Plan in Education: Giving School Back to the Community].

https://coalitionavenirquebec.org/wp-content/uploads/2018/08/plan-de-gouvernance-s colaire-remettre-l-ecole-entre-les-mains-de-sa-communaute.pdf

Charette, J., Kalubi, J., \& Lessard, A. (2019). Intervenants école-familles immigrantes: Défis et perspectives du rôle de médiation [School-Immigrant Family Collaboration: Challenges and Perspectives of the Role of Mediator]. La revue internationale de l'éducation familiale, 45, 23-45. https://doi.org/10.3917/rief.045.0023

https://www.cairn.info/revue-la-revue-internationale-de-l-education-familiale-2019-1page-23.htm

Charrette, J., \& Kalubi, J. C. (2016). Collaborations école-famille-communauté: L’apport de l'intervenant interculturel dans l'accompagnement à l'école de parents récemment immigrés au Québec [School-Family-Community Collaborations: The Intercultural Social Worker as Intermediary between the School and Newly Arrived Immigrants in Québec]. Education Sciences and Society, 2, 127-149.

https://doi.org/10.3280/ess2-20160a3929

http://tcri.qc.ca/images/publications/volets/volet-jeunes/2017/Actes_RN_ICI ENJEUmai 2017-Documents-internes/Josee Charette article 2.pdf

Cook, A. L., Hayden, L. A., Bryan, J., \& Belford, P. (2016). Implementation of a School-Family-Community Partnership Model to Promote Latina Youth Development: Reflections on the Process and Lessons Learned. International Journal of Research on Service-Learning and Community Engagement, 4, 102-116.

https://journals.sfu.ca/iarslce/index.php/journal/article/view/189

CSÉQ Conseil Supérieur de l'Éducation du Québec (2017). Pour une école riche de tous ses élèves: S'adapter à la diversité des élèves, de la maternelle à la $5 e$ année du secondaire [The School Is Only as Good as Its Students: Adapting to Student Diversity from Preschool through High School].

https://www.cse.gouv.qc.ca/publications/ecole-riche-eleves-50-0500/

Deslandes, R. (2019a). Collaborations école-famille-communauté: Recension des écrits tome 1, relations école-famille [School-Family-Community Collaborations: A Review of the Literature. Vol. 1. School-Family Relations].

https://www.periscope-r.quebec/sites/default/files/relations-ecole-famille deslandes 20 19.pdf

Deslandes, R. (2019b). Collaborations école-famille-communauté: Recension des écrits tome 2, relations école-communauté [School-Family-Community Collaborations: $A$ Review of the Literature. Vol. 2. School-Community Relations].

https://www.periscope-r.quebec/sites/default/files/relations-ecole-communaute 2019.p df

Epstein, J. L. (2001). Introduction to the Special Section. New Directions for School, Family, and Community Partnerships in Middle and High Schools. NASSP Bulletin, 85, 3-6. https://doi.org/10.1177/019263650108562701

Epstein, J. L., Sanders, M. G., Sheldon, S. B., Simon, B. S., Salinas, K. C., Jansorn, N. R., Voorhis, F. L. V., Martin, C. S., Thomas, B. G., Greenfeld, M., Hutchins, D. J., \& Williams, K. J. (2019). School, Family, and Community Partnerships: Your Handbook for Action (p. 4). Thousand Oaks, CA: Corwin, A Sage Publishing Company.

Gallos, J. V. (2013). Reframing Organizations: An Instructor's Guide to Effective Teaching (p. 5).

https://www.academia.edu/34736919/USING BOLMAN AND DEALS REFRAMIN 
G ORGANIZATIONS An Instructors Guide to Effective Teaching

Griffin, D., \& Steen, S. (2010). School-Family-Community Partnerships: Applying Epstein's Theory of the Six Types of Involvement to School Counselor Practice. Professional School Counseling, 13, 218-226. https://doi.org/10.5330/PSC.n.2010-13.218

Hallinger, P., \& Heck, R. H. (2010). Leadership for Learning: Does Collaborative Leadership Make a Difference in School Improvement? Educational Management Administration \& Leadership, 38, 654-678. https://doi.org/10.1177/1741143210379060

ISQ Institut de la statistique du Quebec (2017). Le bilan demographique du Quebec: Édition 2017 [Demographic Overview of Québec: The 2017 Edition]. https://numerique.banq.qc.ca/patrimoine/details/52327/36453?docref=D1rFeZkC4xvfs -RLUX6Ksg

Kanouté, F. (2016). Prendre en compte la diversité à l'école en se rappelant sa complexité comme institution [Considering Diversity in the School: A Look at a Complex Institution]. Alterstice, 6, 9-12. https://doi.org/10.7202/1038274ar

Kim, J. (2012). Defining and Assessing Parent Empowerment and Its Relationship to Academic Achievement Using the National Household Education Survey: A Focus on Marginalized Parents.

https://drum.lib.umd.edu/bitstream/handle/1903/13284/Kim umd 0117E 13630.pdf?i sAllowed $=\mathrm{y} \&$ sequence $=1$

Larivée, S. J., Bédard, J., Couturier, Y., Kalubi, J. C., \& Larose, F. (2017). Les pratiques de collaboration école-famille-communauté efficaces ou prometteuses: Synthèse des connaissances et pistes d'intervention [Effective and Winning School-Family-Community Collaboration Practices: What We Know and What We Can Do].

http://www.frqsc.gouv.qc.ca/documents/11326/448958/AP 2014-2015 LariveeS rappo

rt ecole-famille-communaute.pdf.pdf/9a254d5f-da94-47fd-939c-d69f1419b2c5

MEES Ministère de l'Éducation (2020). Soutien au milieu scolaire 2020-2021: Intégration et réussite des éléves issus de l'immigration et éducation interculturelle [Integration and Achievement of Immigrant Students and Intercultural Education].

http://www.education.gouv.qc.ca/fileadmin/site web/documents/education/diversite/G uide-soutien-milieu-scolaire 2020-2021.pdf

MELS Ministère de l'Éducation, du Loisir et du Sport (2014). Cadre de référence: Accueil et intégration des élèves issus de l'immigration au Québec [Reference Guide to Welcoming and Integrating Immigrant-Origin Students in Québec].

http://www.education.gouv.qc.ca/fileadmin/site web/documents/education/diversite/A ccueilIntegration 1 PortraitEleves.pdf

Ministère de l'Éducation du Québec (2006). Programme de formation de l'école québécoise: Enseignement secondaire, premier cycle [Québec Education Training Program: Secondary Education, Cycle 1].

http://www.education.gouv.qc.ca/fileadmin/site web/documents/PFEQ/prfrmseclercy clev2.pdf

Molina, S. C. (2013). Family, School, Community Engagement, and Partnerships: An Area of Continued Inquiry and Growth. Teaching Education, 24, 235-238.

https://doi.org/10.1080/10476210.2013.786894

OFDE Observatoire sur la formation à la diversité et l'équité (2020). Diriger et agir pour l'equite, l'inclusion et la justice sociale: Boîte a outils pour les directions d'etablissement d'enseignement [Leading and Working for Equity, Inclusion, and Social Justice: A Tool Box for School Principals]. https://papyrus.bib.umontreal.ca/xmlui/handle/1866/22946

Pilkiene, M. (2017). The Relationship between School Principals and Teachers' Servant 
Leadership. New Trends and Issues-Proceedings on Humanities and Social Sciences, 4, 114-122. https://doi.org/10.18844/prosoc.v4i3.2523

Sawicki, F. (2003). Leadership Politique: Un concept à remettre sur le métier? [Should We Bring Back Political Leadership?]. In A. Smith, \& C. Sorbets (Eds.), Le leadership politique et le territoire. Les cadres d'analyse en débat (pp. 73-92). Rennes: Presses Universitaires.

Vatz Laaroussi, M., \& Steinbach, M. (2010). Des pratiques interculturelles dans les écoles des régions du Québec: Un modèle à inventer [Intercultural Practices in Québec Schools: Getting Started]. Recherches en éducation, 9, 43-55.

https://www.researchgate.net/profile/Joelle Demougeot-Lebel/publication/49137743 L es charges de TDTP ont-ils tous les memes inquietudes avant leurs premieres in terventions face aux etudiants/links/5c71834c458515831f698daf/Les-charges-de-TDTP-ont-ils-tous-les-memes-inquietudes-avant-leurs-premieres-interventions-face-auxetudiants.pdf\#page $=43$ 